\title{
Oxygen/Glucose Deprivation in Hippocampal Slices: Altered Intraneuronal Elemental Composition Predicts Structural and Functional Damage
}

\author{
Charles P. Taylor, ${ }^{1}$ Mark L. Weber, ${ }^{1}$ Christopher L. Gaughan, ${ }^{2}$ Ellen J. Lehning, ${ }^{2}$ and Richard M. LoPachin ${ }^{2}$ \\ ${ }^{1}$ Department of Neuroscience Therapeutics, Parke-Davis Pharmaceutical Research, Division of Warner-Lambert \\ Company, Ann Arbor, Michigan 48105, and 2Department of Anesthesiology, Albert Einstein College of Medicine, \\ Montefiore Medical Center, Bronx, New York 10467
}

\begin{abstract}
Effects of oxygen/glucose deprivation (OGD) on subcellular elemental composition and water content were determined in nerve cell bodies from CA1 areas of rat hippocampal slices. Electron probe $\mathrm{x}$-ray microanalysis was used to measure percentage water and concentrations of $\mathrm{Na}, \mathrm{P}, \mathrm{K}, \mathrm{Cl}, \mathrm{Mg}$, and $\mathrm{Ca}$ in cytoplasm, nucleus, and mitochondria of cells exposed to normal and oxygen/glucose deficient medium. As an early (2 min) consequence of OGD, evoked synaptic potentials were lost, and $\mathrm{K}, \mathrm{Cl}, \mathrm{P}$, and $\mathrm{Mg}$ concentrations decreased significantly in all morphological compartments. As exposure to in vitro OGD continued, a negative DC shift in interstitial voltage occurred ( $\sim 5 \mathrm{~min})$, whereas general elemental disruption worsened in cytoplasm and nucleus (5-42 min). Similar elemental changes were noted in mitochondria, except that $\mathrm{Ca}$ levels increased during the first $5 \mathrm{~min}$ of OGD and then decreased over the remaining experimental period (12-42 min). Compartmental water content decreased early (2 min), returned to con-
\end{abstract}

trol after 12 min of OGD, and then exceeded control levels at 42 min. After OGD (12 min), perfusion of hippocampal slices with control oxygenated solutions (reoxygenation) for $30 \mathrm{~min}$ did not restore synaptic function or improve disrupted elemental composition. Notably, reoxygenated CA1 cell compartments exhibited significantly elevated $\mathrm{Ca}$ levels relative to those associated with $42 \mathrm{~min}$ of OGD. When slices were incubated at $31^{\circ} \mathrm{C}$ (hypothermia) during OGD/reoxygenation, neuronal dysfunction and elemental deregulation were minimal. Results show that in vitro OGD causes loss of transmembrane $\mathrm{Na}, \mathrm{K}$, and $\mathrm{Ca}$ gradients in CA1 neurons of hippocampal slices and that hypothermia can obtund this damaging process and preserve neuronal function.

Key words: oxygen/glucose deprivation; ischemia; reperfusion injury; CA1 cells; hypothermia; neuroprotection; electron probe $x$-ray microanalysis
Ischemic or hypoxic events rapidly compromise nerve cell function in brain tissues (Hansen, 1985; Erecinska and Silver, 1994; Hossmann, 1996; Silver et al., 1997). Within minutes of oxygen and/or glucose deprivation, cellular ATP levels decrease, excitatory amino acids are released, and cellular ion gradients collapse with resulting membrane depolarization (Siesjo, 1992; Martin et al., 1994). Because neuronal function is critically dependent on maintenance of $\mathrm{Na}^{+}, \mathrm{K}^{+}, \mathrm{Cl}^{-}$, and $\mathrm{Ca}^{2+}$ transmembrane distributions, loss of ion gradients is considered to be a cardinal event in the pathophysiology of brain ischemia (Hansen, 1985; Martin et al., 1994). Results from whole-animal models have suggested that ischemic/hypoxic perturbation of cellular ion regulation can be divided into two phases. Phase 1 is associated with a gradual rise in extracellular $\mathrm{K}^{+}\left(\mathrm{K}^{+}{ }_{\mathrm{o}}\right)$ concentrations, with little change in other ions (Hansen, 1985; Moghaddam et al., 1986; Zetterstrom et al., 1995). As ischemia or hypoxia continues, phase 2 changes develop and consist of an additional large increase in $\mathrm{K}^{+}{ }_{\mathrm{o}}$, a corresponding negative shift in interstitial voltage, and substantial decreases in extracellular $\mathrm{Na}^{+}, \mathrm{Cl}^{-}$, and

Received May 13, 1998; revised Oct. 27, 1998; accepted Nov. 2, 1998.

This study was sponsored by a Research Initiation Grant from Montefiore Medical Center to R.M.L. and E.J.L and by salaries and supplies from Parke-Davis Research Division to C.P.T. and M.L.W. We thank Drs. Peter Lipton, Peter Stys, David Andrews, and Cathryn Jarvis for their helpful comments and criticisms.

Correspondence should be addressed to Dr. Richard M. LoPachin, Anesthesia Research-Moses 7, Montefiore Medical Center, 111 E. 210th Street, Bronx, NY 10467-2490.

Copyright (ㄷ) 1999 Society for Neuroscience $\quad 0270-6474 / 99 / 190619-11 \$ 05.00 / 0$
$\mathrm{Ca}^{2+}$ concentrations (Hansen and Zeuthen, 1981; Harris et al., 1981; Silver and Erecinska, 1990; Somjen et al., 1990). CNS ischemic or hypoxic events in vivo are often transient and are succeeded by regional reperfusion. Despite restoration of normal extraneuronal oxygen tension and glucose content, the reperfusion period can be paradoxically associated with additional nerve cell injury (Siesjo, 1992). This secondary injury involves multiple factors (e.g., free radical generation, mitochondrial dysfunction) that promote additional neuronal $\mathrm{Na}^{+}$and $\mathrm{Ca}^{2+}$ entry (Young, 1986; Siesjo, 1992; Choi, 1995; Kristian and Siesjo, 1996). Thus, disruption of intraneuronal ion balance and $\mathrm{Ca}^{2+}$ overload appear to be critically involved in neuronal cell injury associated with ischemia and reperfusion.

Despite the potential importance of disturbed nerve cell ion homeostasis during transient oxygen/glucose deprivation (OGD), very little direct, detailed information exists regarding corresponding altered intraneuronal disposition of $\mathrm{Na}^{+}, \mathrm{K}^{+}, \mathrm{Ca}^{2+}$, and other ions in brain tissue. In particular, the magnitude and extent of ion translocation among ischemic subcellular organelles and compartments are not known, nor is it understood how these ionic changes relate to ensuing structural and functional alterations. To understand this information gap, we used electron probe $x$-ray microanalysis (EPMA) to determine the effects of OGD and reoxygenation on intracellular distribution of $\mathrm{Na}, \mathrm{K}$, $\mathrm{Ca}$, and other biological elements in CA1 nerve cells from rat hippocampal slices. Both morphology and synaptic function were assessed in these tissue slices, and results were correlated with 
respective EPMA data. EPMA is a quantitative electron microscopy technique that simultaneously measures water content and total (free plus bound) concentrations of elements in selected morphological compartments of rapidly frozen tissue [for detailed technical discussion see LoPachin (1995)]. This technique permits optical identification of individual neurons and analyses of respective subcellular compartments such as mitochondria and nuclei. Microprobe analysis has been used to quantify nervous tissue elemental disturbances in various neuropathological conditions (LoPachin and Lehning, 1997).

\section{MATERIALS AND METHODS}

In the present study, rat hippocampal tissue slices were used, because unlike other in vitro model systems (e.g., cultured embryonic nerve cells), a relatively normal anatomical microenvironment is maintained. Neurons in CA1 regions of these slices were analyzed because these cells are highly sensitive to OGD, and their neuropathological and electrophysiological responses have been well described (Balestrino et al., 1989; Taylor and Weber, 1993; Taylor et al., 1995). Elemental changes induced by OGD or experimental ischemia were measured, therefore, in vulnerable adult CNS neurons under conditions similar to those in vivo. In addition, parallel determinations of synaptic function and histopathology were conducted in the same tissue. Consequently, we were able to correlate onset of elemental disruption with changes in structural and functional parameters. All aspects of this study were in accordance with the NIH Guide for Care and Use of Laboratory Animals and were approved by local animal care committees.

Preparation of hippocampal slices. Methods for hippocampal slice preparation were similar to those discussed in detail elsewhere (Taylor and Weber, 1993; Weber and Taylor, 1994); a brief description is provided here. Male Wistar rats (200-275 gm) were anesthetized with pentobarbital $(50 \mathrm{mg} / \mathrm{kg}$, i.p.) and decapitated. Brains were rapidly excised and placed in cold $\left(4^{\circ} \mathrm{C}\right)$ oxygenated artificial CSF (aCSF) containing (in mM): $\mathrm{NaCl} 125, \mathrm{KCl} 3.5, \mathrm{MgSO}_{4} 1.0, \mathrm{CaCl}_{2} 2.0, \mathrm{NaHCO}_{3} 26, \mathrm{NaH}_{2} \mathrm{PO}_{4}$ 1.25 , and D-glucose 10 . Cooled brains were hemisected at the midline and trimmed, leaving a rectangular block of tissue that included the dorsal hippocampus. The tissue block was glued to the stage of a vibrating slicer (Campden Instruments Vibroslice $752 \mathrm{M}$ ) and sectioned coronally (450 $\mu \mathrm{m})$ at low temperatures $\left(0^{\circ} \mathrm{C}\right)$. A small number of randomly selected fresh slices were quench-frozen or conventionally fixed immediately after Vibroslice cutting (see below). The majority of slices were placed in an interface recording chamber (Scientific Systems Design) at room temperature and preincubated for $1-2 \mathrm{hr}$ by superfusion with aCSF that was gradually warmed to $36^{\circ} \mathrm{C}$. Slices were superfused continuously $(1 \mathrm{ml} /$ min) with either normal aCSF (control) or OGD medium. Extracellular glass micropipettes containing $2 \mathrm{M} \mathrm{NaCl}(4-10 \mathrm{M} \Omega$ resistance) were placed into the stratum radiatum of the CA1 region and used to record EPSPs in response to stimuli ( $40-150 \mu \mathrm{A}, 0.4 \mathrm{msec}$ pulses) from paired wire electrodes placed $\sim 1 \mathrm{~mm}$ from the recording site. Voltage recordings were made with an electrometer (Axon Instruments Axoprobe 200), and evoked potentials were stored digitally once every $60 \mathrm{sec}$. A continuous strip-chart record was used to observe DC negative shifts (5-25 $\mathrm{mV}$ ), which are similar in waveform to spreading depression that follows brain oxygen and glucose deprivation.

Light microscopy. For morphological observations in conventionally fixed hippocampal tissues, representative slices were selected immediately after Vibroslice cutting or were removed from the incubation medium at selected experimental times and fixed overnight by immersion in Bouin's solution $\left(27^{\circ} \mathrm{C}\right)$. After fixation, slices were alcohol-dehydrated, infiltrated with paraffin, and sectioned $(3 \mu \mathrm{m})$. Sections were mounted on glass slides, stained with hematoxylin/eosin, and examined on an upright compound microscope and photographed.

In vitro $O G D$. OGD was produced by superfusing slices with D-glucose-deficient aCSF equilibrated with a $95 \% \mathrm{~N}_{2} / 5 \% \mathrm{CO}_{2}$ gas mixture (Weber and Taylor, 1994). Oxygen tension of the oxygen/glucosedeficient aCSF was $5 \%$ or lower, as determined with polarized glassinsulated carbon-fiber electrodes. Oxygen tension measured $\sim 100 \mu \mathrm{m}$ below the tissue surface fell to near zero within $30 \mathrm{sec}$ of initiating oxygen/glucose deprivation. Slices $(n=5-8$ per experimental group) were removed from the perfusion chamber after $0,2,5,12$, and $42 \mathrm{~min}$ of OGD exposure. To assess post-OGD recovery of neuronal water content and elemental composition, slices $(n=6)$ were exposed to $12 \mathrm{~min}$ of experimental ischemia and then returned to oxygenated, glucose- containing medium for $30 \mathrm{~min}$ (reoxygenation). As a control for the OGD and reoxygenation periods, slices $(n=3$ per time point) were incubated with normal aCSF for 12 and $42 \mathrm{~min}$ beyond the initial equilibration time $(t=0$; see above). Results demonstrated that respective elemental data for $t=0,12$, and 42 min non-OGD control incubations were not statistically different and therefore were pooled. As an additional study to determine the effects of excision and subsequent preincubation procedures on recovery of intraneuronal elemental composition, a separate group of slices $(n=6)$ were quench-frozen or conventionally fixed immediately after Vibroslice cutting; i.e., slices received no in vitro incubation. The neuroprotective capacity of mild hypothermia was also determined in the in vitro OGD/reoxygenation model. Slices $(n=7)$ were superfused with cooled $\left(31^{\circ} \mathrm{C}\right)$ oxygen/ glucose-deficient aCSF for $12 \mathrm{~min}$ and then exposed to cooled $\left(31^{\circ} \mathrm{C}\right)$ normal oxygenated solutions for $30 \mathrm{~min}$. As a control, slices $(n=4)$ were incubated in oxygenated, glucose-containing aCSF for $42 \mathrm{~min}$ at $31^{\circ} \mathrm{C}$. This control hypothermic period did not modify neuronal elemental composition relative to control incubations at $36^{\circ} \mathrm{C}$ (i.e., pooled 0,12 , and 42 min control data; see above). At the end of each experimental or control period, tissue samples were rapidly removed from the incubation chamber and were immediately quench-frozen by immersion in melting isopentane. Frozen slices were then stored in liquid nitrogen for later analysis.

Cryoultramicrotomy and EPMA. The methodologies for cryomicrotomy and EPMA have been published extensively (Saubermann et al., 1981a,b; Foster and Saubermann, 1991; LoPachin et al., 1991; LoPachin, 1995). Briefly, frozen hippocampal slices were sectioned $(500 \mathrm{~nm}$ nominal thickness) on a cryomicrotome at an ambient cryochamber temperature of $-55^{\circ} \mathrm{C}$. Unstained, unfixed, hydrated cryosections were then transferred under vacuum to the cold stage $\left(-185^{\circ} \mathrm{C}\right)$ of an AMRay 1000 scanning electron microscope. The electron microscope was equipped with a Tracor Northern energy dispersive detector and pulse processor that was connected to a PC-based multichannel analyzer for collection and processing of x-rays (Foster and Saubermann, 1991). For quantitative analyses of elements in hippocampal cryosections, wet-weight specimen mass was measured in frozen hydrated sections by determining continuum generation rates (Saubermann et al., 1981a,b; Saubermann and Heyman, 1987). Cryosections were then dehydrated in the electron microscope column vacuum by raising the temperature of the cold stage from -185 to $-60^{\circ} \mathrm{C}$ for $30 \mathrm{~min}$. Stage temperature was returned to $-185^{\circ} \mathrm{C}$ for microanalysis. The electron beam $(20 \mathrm{kV}, 0.4 \mathrm{nA}$ current $)$ was rastered within anatomical boundaries of the chosen structures. $\mathrm{X}$-ray spectra were collected over $100 \mathrm{sec}$ of live counting time. Dry weight elemental mass fractions (millimoles/kilogram of dry weight) for $\mathrm{Na}, \mathrm{K}, \mathrm{P}, \mathrm{Cl}, \mathrm{Mg}$, and $\mathrm{Ca}$ were determined using software applying the Hall et al. (1973) method of continuum normalization (Foster and Saubermann, 1991; Saubermann et al., 1992). Water content (percentage water) of morphological compartments was determined by the ratio of respective continuum counts in hydrated versus dried states (Bulger et al., 1981; Saubermann et al., 1981b). EPMA does not distinguish ionic versus bound element but rather measures total elemental concentrations. Therefore, symbols for each element are expressed without oxidation state (e.g., K) when corresponding concentrations have been derived by EPMA. Oxidation states are indicated (e.g., $\mathrm{K}^{+}$) for discussions of previous research involving ion-sensitive measurements or for physiological processes (e.g., membrane transport) in which involvement of the ionized species is implicit.

Compartment identification. Morphological compartments (cytoplasm, nuclei, and mitochondria) were visualized in dehydrated cryosections using scanning-transmission electron microscopy. Spatial resolution in unfixed, unstained hippocampal cryosections is not sufficient to distinguish individual submitochondrial cytoplasmic constituents. Thus, "cytoplasm" is a primarily a composite measurement of Nissl substance, Golgi apparatus, and microtubule/neurofilament regions (Peters et al., 1991). The nuclear compartment represents EPMA of nucleoplasm and excludes analysis of the nucleolus. CA1 cell mitochondria in frozen hippocampal sections appeared as dense (cristea are not visible), multivariate forms (spherical to slender rodlets) with dimensions of $\sim 0.1 \mu \mathrm{m}$ diameter and $0.1-0.5 \mu \mathrm{m}$ length. In the absence of positive identification, it is possible that corresponding EPMA data are contaminated by analyses of similarly sized cytoplasmic objects such as lysosomes or lipof uscin granules. However, several observations suggest that the mitochondrial compartment is appropriately identified. Mitochondria and other subcellular organelles or areas can be differentiated by elemental composition and water content. For example, relative to other compartments, lyso- 

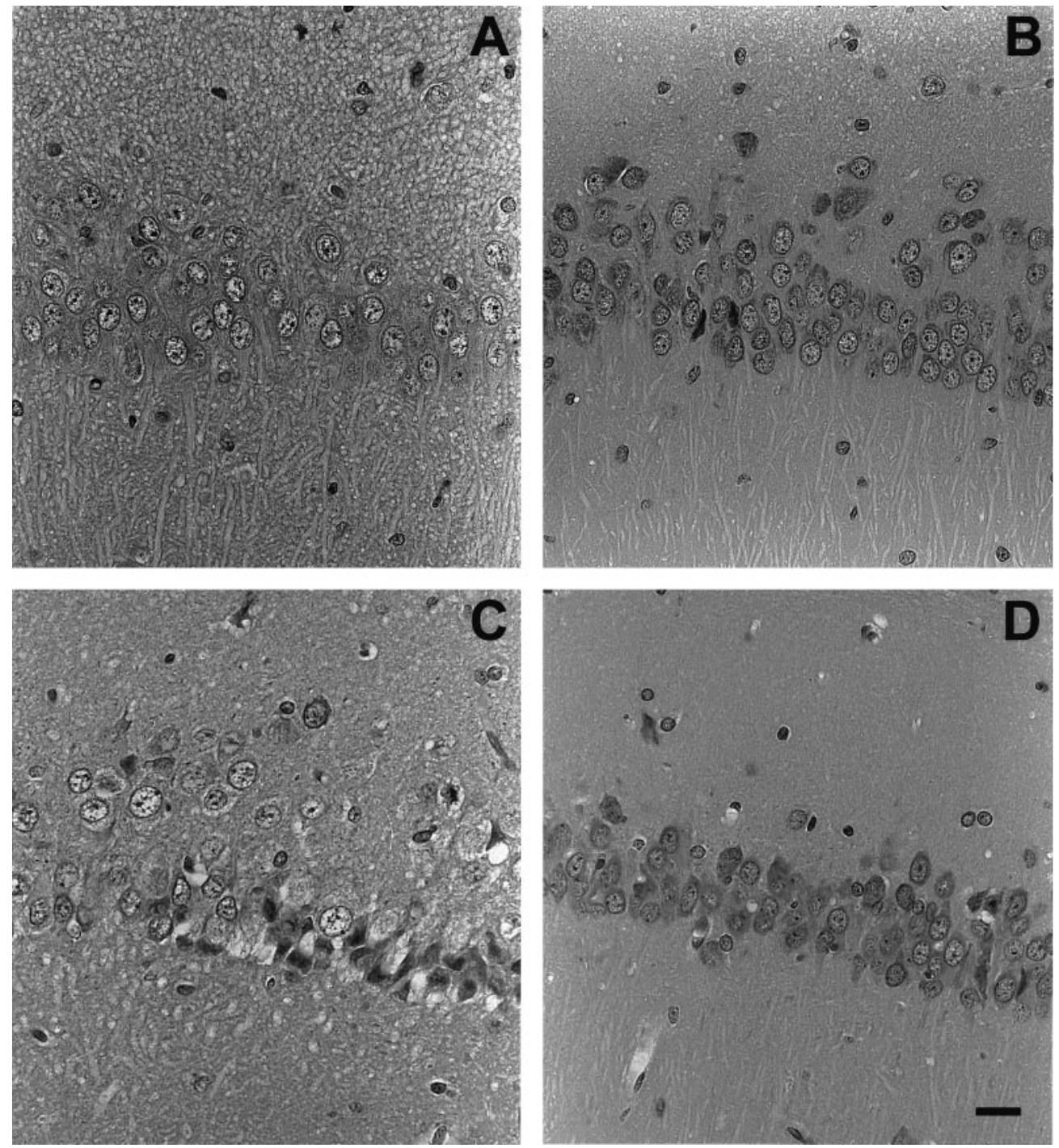

Figure 1. Hematoxylin and eosinstained sections $(3-\mu \mathrm{m}$-thick) illustrating changes in slice morphology as a function of different incubation conditions. $A$, Tissue fixed immediately after slicing (nonincubated). Note swollen pyramidal cell nuclei and dendritic shafts, as well as pronounced blebbing (granular appearance) in dendritic areas. $B$, Slice fixed after $\sim 1.5 \mathrm{hr}$ of incubation in normal aCSF at $36^{\circ} \mathrm{C}$. Neuronal perikarya, nuclei, and apical dendrites exhibit nearly normal appearance. $C$, Tissue fixed after incubation for $1.5 \mathrm{hr}$ in normal aCSF at $36^{\circ} \mathrm{C}$ followed by 12 min ischemia and $30 \mathrm{~min}$ reperfusion. Grossly swollen CA1 neuronal cell bodies and nuclei were observed with some disintegrated somata and others that stained darkly (pyknosis). Dendritic areas are highly granular, and individual dendritic shafts cannot be distinguished. $D$, Tissue fixed after incubation for 1.5 $\mathrm{hr}$ in normal aCSF at $31^{\circ} \mathrm{C}$ followed by $12 \mathrm{~min}$ ischemia and $30 \mathrm{~min}$ reperfusion. Preservation of histological features is remarkable and is similar in appearance to hippocampal regions of brain fixed in situ by cardiac perfusion (data not shown). Scale bar, $25 \mu \mathrm{m}$ (for all micrographs). somes exhibit very high sulfur concentrations because of the prevalence of S-containing enzymes (LeFurgey et al., 1991; R. L. Pachin and E. Lehning, unpublished data). When compared with respective cytoplasm (see Table 2), mitochondria from CA1 cells maintained in control conditions exhibited higher $\mathrm{Na}, \mathrm{P}$, and $\mathrm{Cl}$ concentrations $(p<0.05)$ and a lower water content $(p<0.05)$. Furthermore, mitochondria can be distinguished by function. Thus, observed $\mathrm{Ca}$ sequestration and accumulation by our mitochondrial compartment during OGD/reoxygenation (see Results) are predictable behaviors based on presumed pathophysiological roles. Therefore, the present mitochondria data likely reflect compartment-specific analyses [see also LoPachin et al. (1988) and LoPachin and Stys (1995)].

Statistics. Nested ANOVA was used to show that analyses of nerve cells from individual slices of an experimental group could be pooled to derive a group mean. Therefore, descriptive parameters such as group means and SE of the mean are not based on number of slices (e.g., $n=3-4$ per time point), but rather are derived from pooled nerve cell data. Statistical differences $(p<0.05)$ among group means were determined using one-factor ANOVA followed by Dunnett's test modified for unbalanced data.

\section{RESULTS}

\section{CA1 cell neuropathology}

In cryosections from control oxygenated hippocampal slices, the CA1 region was easily identified, and cellular morphology of respective pyramidal-shaped neurons was well preserved, i.e., cytoplasm, mitochondria, nuclei, and apical dendrites were readily evident. Morphological observations of cryosections from frozen slices exposed to $12 \mathrm{~min}$ of OGD indicated minimal neuropathic disruption. However, $42 \mathrm{~min}$ of OGD or $12 \mathrm{~min}$ OGD/30 min reoxygenation produced similar dendritic blebbing with pronounced somatic and mitochondrial swelling. Parallel examination of conventionally fixed, paraffin-imbedded sections (Fig. 1) confirmed morphological findings in cryosections. Light microscopy of slices fixed immediately after Vibroslice preparation (Fig. $1 A$ ) indicated significant swelling of pyramidal neurons, i.e., cell bodies, mitochondria, dendrites, and nuclei were enlarged and hydropic. After $1.5 \mathrm{hr}$ of incubation in control aCSF, pyramidal neurons had a normal appearance, with compact nuclei, normal nucleoli, narrower primary dendrites, and no evidence of dendritic blebbing (Fig. 1B). However, after 12 min of $\mathrm{OGD}$ and $30 \mathrm{~min}$ of reoxygenation at $36^{\circ} \mathrm{C}$, tissue morphology was severely disrupted (Fig. $1 C$ ) and was characterized by darkly stained, swollen perikarya, mitochondria, and nuclei, grossly disrupted cell bodies, and blebbed dendrites. In contrast, slices removed after $12 \mathrm{~min}$ of OGD and $30 \mathrm{~min}$ reoxygenation at $31^{\circ} \mathrm{C}$ (Fig. 1D) exhibited excellent histological appearance, including compact cell bodies and nuclei, and dendrites without blebbing. 
A
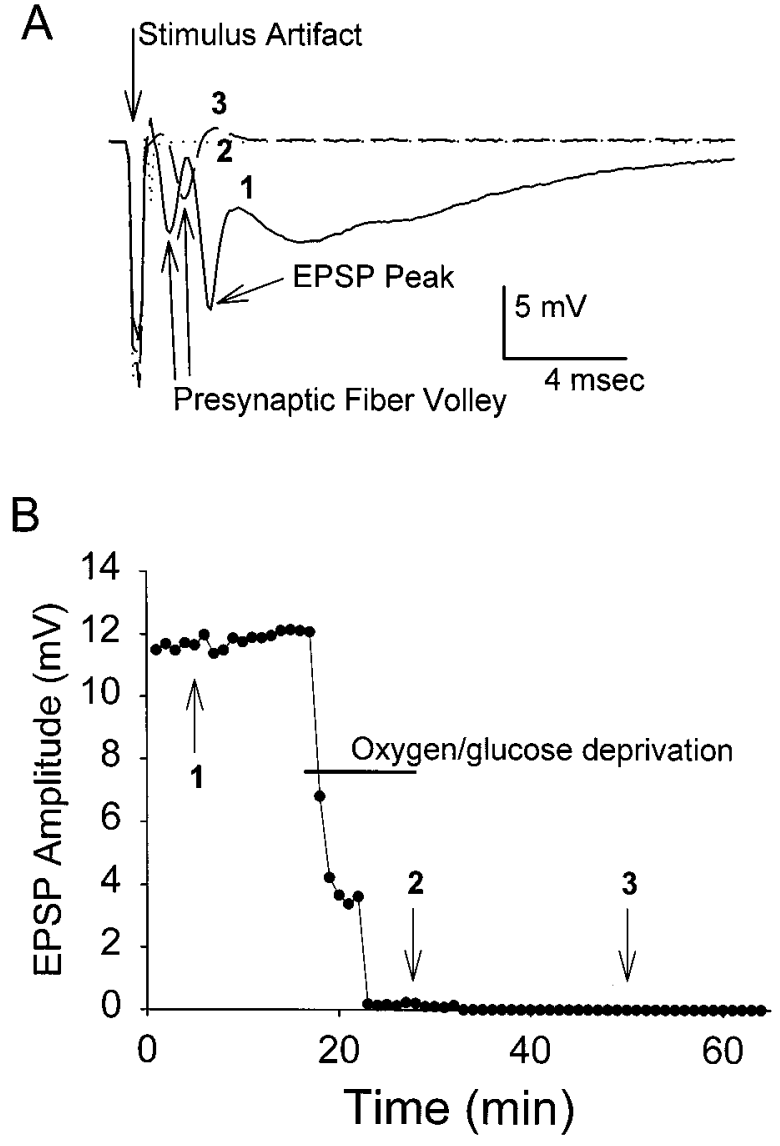

Figure 2. Evoked EPSPs were recorded at $1 \mathrm{~min}$ intervals throughout a representative OGD experiment $\left(36^{\circ} \mathrm{C}\right)$. $A$, EPSP waveform evoked by 0.4 msec stimulus of Shaffer collaterals before OGD (1; solid trace), loss of EPSP and presynaptic fiber volley at end of OGD (2; dotted trace), and recovery of fiber volley (but not EPSP) $20 \mathrm{~min}$ after OGD (3; dashed trace). $B$, The maximal EPSP amplitude was plotted throughout a representative experiment. In this example, EPSPs were irreversibly lost after 12 min of OGD. Numerals refer to individual traces from $A$. Note that with lowered temperature, most slices recovered EPSPs after OGD (Table 1).

\section{Electrophysiology}

Normal synaptic evoked potentials [i.e., similar in waveform to those occurring in vivo (Andersen and Lomo, 1966)] were observed in CA1 stratum radiatum before OGD (mean amplitude was $5.2 \pm 0.44 \mathrm{mV}, n=38$ ) (Fig. $2 A$ ). As reported previously (Weber and Taylor, 1994), extracellular EPSPs disappeared within $5 \mathrm{~min}$ of OGD onset (Fig. $2 B$ ). Subsequently, a negative DC voltage shift $(5-25 \mathrm{mV})$ was seen in all slices that were oxygen/glucose-deprived for $12 \mathrm{~min}$ at $36^{\circ} \mathrm{C}$ (Table 1). Previous studies have shown that such negative shifts correspond to cellular depolarization and large changes in extracellular ionic composition (Hansen, 1985). The mean time to negative shift in all slices exposed to either 12 or $42 \mathrm{~min}$ of OGD was $\sim 5 \mathrm{~min}$ at $36^{\circ} \mathrm{C}$ (Table 1). Evoked EPSPs were measured in groups of slices exposed to OGD/reoxygenation at either $36^{\circ} \mathrm{C}$ or $31^{\circ} \mathrm{C}$. None of the slices kept at $36^{\circ} \mathrm{C}$ had EPSPs that were at least $50 \%$ of starting amplitude, which indicates a loss of normal synaptic function. In contrast, all slices subjected to OGD at $31^{\circ} \mathrm{C}$ had EPSPs that recovered during reoxygenation (Table 1). Furthermore, less than half of these slices displayed a DC negative shift during the 12 min OGD period; negative shifts that were ob- served were significantly delayed (Table 1$)$. These results confirm previous reports (Weber and Taylor, 1994) of hypothermia $\left(31^{\circ} \mathrm{C}\right)$ as a neuroprotectant.

\section{Elemental composition and water content of CA1 nerve cells from control incubated and nonincubated hippocampal slices}

Analyses of nerve cells from nonincubated slices (i.e., slices prepared and frozen immediately without in vitro incubation) revealed gross morphological changes (Fig. 1A) in conjunction with losses of transmembrane elemental gradients and osmoregulation; i.e., in all subcellular compartments, intracellular water content and $\mathrm{Na}, \mathrm{Cl}$, and $\mathrm{Ca}$ concentrations increased significantly, whereas $\mathrm{K}, \mathrm{P}$, and $\mathrm{Mg}$ levels decreased (Table 2). This initial excision trauma was reversible, however. When hippocampal slices were isolated and incubated under control conditions described in Materials and Methods, CA1 cell morphological characteristics (Fig. 1B) and subcellular elemental composition and water contents were normalized (Table 2). In fact, cytoplasmic distributions of $\mathrm{Na}, \mathrm{K}, \mathrm{Cl}$, and other elements in these recovered control cells were quantitatively similar to the EPMAdetermined elemental composition of rat cortical neurons that were rapidly frozen in situ (Table 3). This indicates that cells maintained under our in vitro conditions can establish subcellular ion distributions similar to those in vivo. Electrically evoked EPSPs determined in control incubated slices also were similar to those recorded in other in vivo studies (Table 1), which implies normal ion channel function and neurotransmission. Together, these findings suggest that the methods used for excision and slice preparation in the present studies prevent irreversible damage by promoting restoration of ion gradients and recovery of CA1 nerve cell function.

Table 2 also shows the elemental composition and water content of subcellular compartments from CA1 hippocampal neurons incubated in control conditions. Mean ( \pm SEM) dry weight $\mathrm{Na}$, $\mathrm{Cl}, \mathrm{Mg}$, and $\mathrm{Ca}$ concentrations (millimoles of element per kilogram) were similar regardless of compartment examined. Compartments were distinguished by differences in $\mathrm{P}, \mathrm{K}$, and water content. Mean $\mathrm{P}$ and $\mathrm{K}$ concentrations were lower in cytoplasm when compared with mitochondria or nucleus, whereas water content of cytoplasm was higher than that of the other compartments (Table 2).

\section{Elemental composition and water content of CA1 nerve cells from oxygen/glucose-deprived hippocampal slices}

OGD caused a progressive loss of elemental regulation in cytoplasm, mitochondria, and nucleus of CA1 nerve cells that correlated temporally with the onset of DC negative shifts and disappearance of evoked EPSPs. Figure 3 shows that after 2 min of experimental ischemia, the $\mathrm{K}$ content of all compartments was significantly decreased. Concomitant reductions in $\mathrm{Cl}, \mathrm{Mg}$, and $\mathrm{P}$ concentrations were also observed (Table 4), whereas $\mathrm{Ca}$ content of nucleus increased modestly at this time point (Fig. 3). These early elemental changes coincided with the onset of electrically evoked failure of EPSPs; i.e., EPSPs disappeared $~ 1.5$ min after OGD onset. As oxygen/glucose deprivation continued, large negative shifts in extracellular voltages became more prevalent (mean of $4.8 \pm 0.7 \mathrm{~min}$ post-OGD initiation) (Table 1). During the 5-42 min interval, compartmental $\mathrm{K}$ (Fig. 3), P, and $\mathrm{Mg}$ (Table 4) losses worsened progressively, whereas Na concentrations (Fig. 3) increased. Cytoplasmic Ca levels increased substan- 


\begin{tabular}{|c|c|c|c|}
\hline $\begin{array}{l}\text { Experimental } \\
\text { condition }\end{array}$ & $\begin{array}{l}\text { Percentage of } \\
\text { slices with DC } \\
\text { negative shift }(n)\end{array}$ & $\begin{array}{l}\text { Onset of DC } \\
\text { negative shift }(n)\end{array}$ & $\begin{array}{l}\text { Evoked EPSP (percentage } \\
\text { of initial EPSP amplitude) }\end{array}$ \\
\hline Control & $0(0 / 9)^{a}$ & & $110 \pm 11^{c}$ \\
\hline OGD (2 min) & $33(2 / 6)$ & $1.0(2)^{b}$ & \\
\hline OGD (5 min) & $67(4 / 6)$ & $1.5 \pm 0.5$ & \\
\hline OGD (12 min) & $100(5 / 5)$ & $4.75 \pm 1.3$ & \\
\hline OGD (42 min) & $100(8 / 8)$ & $5.00 \pm 1.9$ & \\
\hline $\mathrm{OGD} / \mathrm{ROX}-36^{\circ} \mathrm{C}$ & $100(6 / 6)$ & $5.9 \pm 0.75(6)$ & $16 \pm 8.5$ \\
\hline $\mathrm{OGD} / \mathrm{ROX}-31^{\circ} \mathrm{C}$ & $43(7 / 7)$ & $8.5 \pm 0.76(3)$ & $65 \pm 16$ \\
\hline
\end{tabular}
${ }^{a}$ Ratio in parentheses is number of slices exhibiting DC negative shift per total number of slices in experimental group.
${ }^{b}$ Onset (mean minutes of oxygen/glucose deprivation \pm SEM) of DC negative shift for those slices $(n)$ exhibiting a shift
during the OGD period. See Materials and Methods for electrophysiological protocol.
${ }^{c}$ Differences among treatment and control groups were statistically significant ( $p<0.05$; Kruskal-Wallis on rank ANOVA
with Bonferroni correction).

Table 2. Elemental composition and water content of CA1 nerve cells from control incubated and nonincubated hippocampal slices

\begin{tabular}{|c|c|c|c|c|c|c|c|}
\hline & $\mathrm{Na}$ & $\mathrm{P}$ & $\mathrm{Cl}$ & $\mathrm{K}$ & $\mathrm{Ca}$ & $\mathrm{Mg}$ & Water \\
\hline \multicolumn{8}{|l|}{ Cytoplasm } \\
\hline Incubated control (93) & $252 \pm 11$ & $609 \pm 35$ & $265 \pm 17$ & $662 \pm 32$ & $5 \pm 1$ & $25 \pm 4$ & $75 \pm 1$ \\
\hline Nonincubated (61) & $1290 \pm 41 *$ & $495 \pm 18^{*}$ & $823 \pm 31^{*}$ & $122 \pm 4^{*}$ & $31 \pm 5^{*}$ & $7 \pm 1^{*}$ & $82 \pm 1^{*}$ \\
\hline \multicolumn{8}{|l|}{ Mitochondria } \\
\hline Incubated control (46) & $321 \pm 18$ & $776 \pm 70$ & $351 \pm 28$ & $739 \pm 38$ & $3 \pm 1$ & $29 \pm 8$ & $63 \pm 1$ \\
\hline Nonincubated (25) & $1420 \pm 68^{*}$ & $525 \pm 17^{*}$ & $984 \pm 41^{*}$ & $126 \pm 6^{*}$ & $51 \pm 12^{*}$ & $1 \pm 1^{*}$ & $72 \pm 1^{*}$ \\
\hline \multicolumn{8}{|l|}{ Nucleus } \\
\hline Incubated control (29) & $232 \pm 22$ & $758 \pm 81$ & $254 \pm 31$ & $807 \pm 75$ & $6 \pm 1$ & $31 \pm 6$ & $62 \pm 1$ \\
\hline Nonincubated (26) & $1330 \pm 46^{*}$ & $458 \pm 12^{*}$ & $964 \pm 32^{*}$ & $117 \pm 4^{*}$ & $26 \pm 5^{*}$ & $2 \pm 1^{*}$ & $75 \pm 1^{*}$ \\
\hline
\end{tabular}

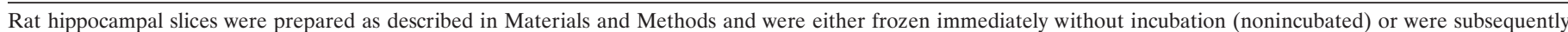

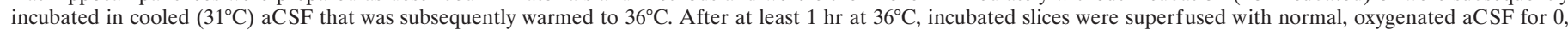

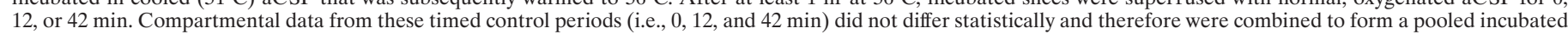

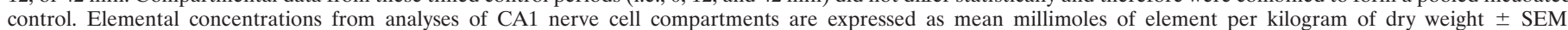

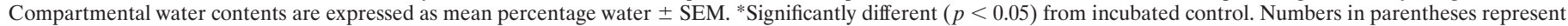
compartmental analyses per experimental group.

\begin{tabular}{lcc}
\hline $\begin{array}{l}\text { Table 3. Elemental composition of cortical and CA1 nerve cell } \\
\text { cytoplasm }\end{array}$ \\
Element & Cortical cells & CA1 cells \\
\hline $\mathrm{Na}$ & $293 \pm 9$ & $252 \pm 11$ \\
$\mathrm{P}$ & $516 \pm 18$ & $574 \pm 25$ \\
$\mathrm{Cl}$ & $167 \pm 5$ & $265 \pm 17$ \\
$\mathrm{~K}$ & $600 \pm 16$ & $662 \pm 32$ \\
$\mathrm{Ca}$ & $6 \pm 1$ & $5 \pm 1$ \\
$\mathrm{Mg}$ & $42 \pm 2$ & $24 \pm 3$
\end{tabular}

$\overline{\text { Data for cortical cells are from Somlyo et al. (1985). Rat cortex was rapidly frozen }}$ in situ by pressing a solid plug of liquid nitrogen-cooled Freon 22 to the exposed brain surface. Frozen tissue was removed, cryosectioned, and then analyzed by EPMA. Control CA1 cell data are from the current study (Table 2). Data are expressed as mean millimoles of element per kilogram of dry weight \pm SEM.

tially (Fig. 3A), whereas in mitochondrial (Fig. 3B) and nuclear (Fig. $3 C$ ) areas, Ca concentrations increased significantly at 5 min and then decreased after 12 min of experimental ischemia. Cytosolic water content was significantly decreased after 2 min of OGD and then returned toward control over the next $10 \mathrm{~min}$, whereas the water contents of mitochondria and nucleus remained unchanged during 12 min of OGD (Table 4). However, all compartments exhibited significant increases in percentage water after $42 \mathrm{~min}$ of OGD exposure (Table 4 ).
To assess the ability of oxygen/glucose-deprived neurons to recover normal elemental composition and synaptic function, hippocampal slices were exposed to OGD and subsequently perfused with normal oxygenated aCSF superfusion (reoxygenation). Results show that regardless of morphological compartment examined, reoxygenation failed to restore normal elemental distribution and evoked EPSPs (Fig. 4, Table 1). In fact, the magnitude of element and water deregulation associated with 12 min of OGD was worsened by $30 \mathrm{~min}$ of subsequent reoxygenation (Fig. 4). The OGD/reoxygenation sequence produced levels of element and water deregulation that were comparable to disruption induced by $42 \mathrm{~min}$ of OGD (Fig. 4). Compartmental Ca responses to reoxygenation, however, were a notable exception; i.e., $\mathrm{Ca}$ concentrations were significantly higher in reoxygenated cells when compared with $\mathrm{Ca}$ levels of neurons subjected to 42 min of OGD (Fig. 4).

\section{Neuroprotective effects of mild hypothermia}

To determine whether hypothermia might be neuroprotective, nerve cell elemental composition and water contents were determined in hippocampal slices incubated at $31^{\circ} \mathrm{C}$ during both oxygen/glucose deprivation (12 $\mathrm{min})$ and subsequent superfusion with normal aCSF (30 min). Figure $5 A$ shows that when compared with the severe elemental deregulation induced by OGD/ reoxygenation at $36^{\circ} \mathrm{C}$, superfusion at $31^{\circ} \mathrm{C}$ significantly reduced 

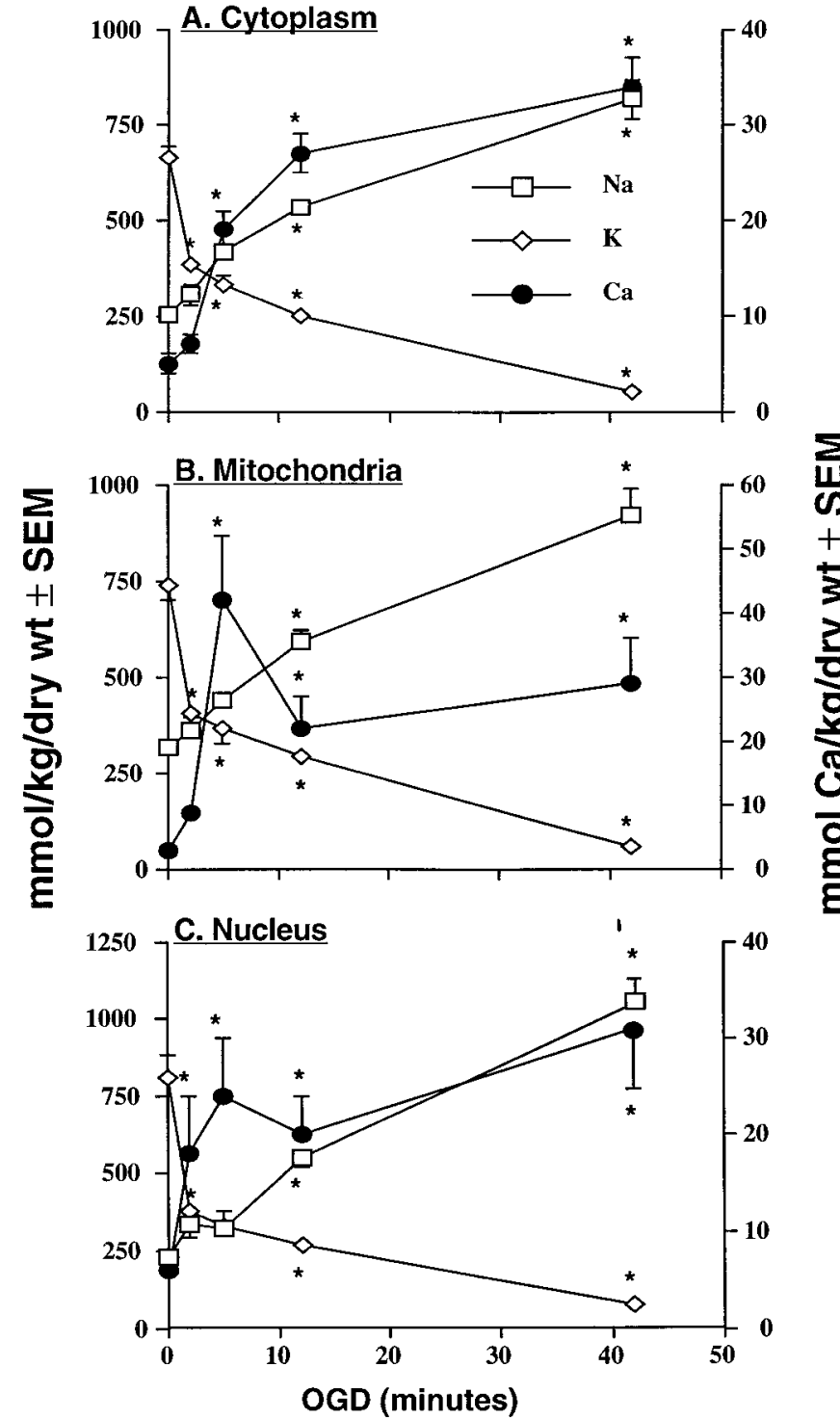

Figure 3. Mean $( \pm$ SEM) dry weight $\mathrm{Na}, \mathrm{K}$, and $\mathrm{Ca}$ concentrations (millimoles of element per kilogram) in cytoplasm (A3), mitochondria (B3), and nucleus (C3) of CA1 nerve cells from rat hippocampal slices. Slices were exposed to oxygen/glucose-deficient aCSF for $2,5,12$, or 42 min. Zero (0) time $=$ pooled control data as presented in Table 2. Number of analyses per compartment is presented in Table 4. Left ordinate is concentration scale for $\mathrm{Na}$ and $\mathrm{K}$; right ordinate is the $\mathrm{Ca}$ scale. ${ }^{*}$ indicates significantly different $(p<0.05)$ from time $(0)$ control.

cytoplasmic $\mathrm{Na}$ and $\mathrm{Ca}$ accumulation and retarded $\mathrm{K}$ loss. In addition, mild hypothermia modified the derangement of cytoplasmic water content and $\mathrm{P}, \mathrm{Cl}$, and $\mathrm{Mg}$ concentrations normally associated with reoxygenation (Table 4). Hypothermic incubation completely prevented reoxygenation-induced mitochondrial $\mathrm{Na}$ and $\mathrm{Cl}$ accumulation (Fig. $5 B$ ) and truncated $\mathrm{K}$ loss and $\mathrm{Ca}$ gain; e.g., in hypothermic conditions mitochondria lost only $22 \%$ of their $\mathrm{K}$ content as opposed to an $81 \%$ loss during normothermic reperfusion. Mitochondrial $\mathrm{Mg}$ and water contents in hypothermic cells did not differ from control, whereas $\mathrm{P}$ levels were decreased modestly (Table 4). Nuclear regions from hypothermic nerve cells exhibited nearly normal elemental composition and water content. Dry weight concentrations of $\mathrm{Na}$ and $\mathrm{Ca}$ were similar to control, whereas nuclear $\mathrm{K}$ was reduced slightly; i.e., $\mathrm{K}$ content decreased only $16 \%$ in hypothermic conditions versus an $84 \%$ reduction during normothermic reperfusion (Fig. 5C). Reoxygenation during hypothermia prevented nuclear changes in $\mathrm{Mg}$ and water, although $\mathrm{P}$ levels were below control values (Table 4). These improvements in compartmental elemental composition and water content corresponded to a mean recovery of $65 \%$ EPSP magnitude (Table 1).

\section{DISCUSSION}

\section{Effects of OGD on element and water deregulation in CA1 nerve cells}

Oxygen/glucose deprivation produced early-onset loss of synaptic function and progressive element and water deregulation in CA1 neurons. Within 2 min of OGD, evoked EPSPs failed, and cytoplasm, mitochondria, and nuclei exhibited substantial decreases in $\mathrm{K}$ with smaller reductions in $\mathrm{Mg}, \mathrm{Cl}$, and $\mathrm{P}$ concentrations. Loss of neuronal $\mathrm{K}$ probably occurs secondary to reduced $\mathrm{Na}^{+}-\mathrm{K}^{+}$ ATPase activity. The precise mechanism of $\mathrm{K}^{+}$efflux during experimental ischemia/anoxia is unknown, although several lines of evidence implicate membrane leak in conjunction with increased $\mathrm{K}^{+}$conductance via ionotropic glutamate receptors (AMPA, NMDA receptors) or through voltage- or ATP-sensitive $\mathrm{K}^{+}$channels (Leblond and Krnjevic, 1989; Jiang and Haddad, 1991; Siesjo, 1992; Zetterstrom et al., 1995). Regardless, intraneuronal $\mathrm{K}$ loss is the likely basis of elevated $\mathrm{K}^{+}$o identified previously (Hansen et al., 1982; Lipton and Whittingham, 1982; Enseleit et al., 1984; Murphy and Greenfield, 1992). K efflux during OGD was associated with decreases in cytoplasmic $\mathrm{Cl}, \mathrm{P}$, and water in all neuronal compartments. More than likely $\mathrm{Cl}$ and $\mathrm{P}$ reductions counterbalance cation $\left(\mathrm{K}^{+}\right)$loss. At physiological $\mathrm{pH}$, inorganic $\mathrm{P}$ is present in two anionic forms: $\mathrm{HPO}_{4}{ }^{-}$and $\mathrm{H}_{2} \mathrm{PO}_{4}{ }^{2-}$, which in conjunction with $\mathrm{Cl}^{-}$efflux might maintain electroneutrality. Currently, the mechanism of outward $\mathrm{HPO}_{4}{ }^{-}$/ $\mathrm{H}_{2} \mathrm{PO}_{4}{ }^{2-}$ transport in neurons is unknown. A significant increase in nuclear $\mathrm{Ca}$ content was also an early consequence of experimental ischemia. This selective effect is consistent with previous studies demonstrating a rapid and large $\mathrm{Ca}^{2+}$ rise in nuclei of glutamate-stimulated or $\mathrm{K}^{+}$-depolarized nerve cells (HernandezCruz et al., 1990; Przywara et al., 1991; Kocsis et al., 1993).

After $5 \mathrm{~min}$ of OGD, and in very close association with the onset of negative DC shifts, elemental disruption in CA1 nerve cells worsened. This was particularly evident in cytoplasm where mean $\mathrm{Na}$ and $\mathrm{Ca}$ levels rose significantly, whereas $\mathrm{Mg}$ and $\mathrm{K}$ continued to decline. These findings support the suggestion that OGD-induced DC shifts or spreading depression-like depolarizations are principally mediated by increased $\mathrm{K}^{+}$conductance with subsequent elevation of extraneuronal $\mathrm{K}^{+}$(Hansen, 1985; Katsura et al., 1992; Zetterstrom et al., 1995). Our data also show that an initial loss of transmembrane $\mathrm{K}^{+}$gradients and depolarization are linked to an acceleration of general ion disruption (Martin et al., 1994). Previous hippocampal slice studies have demonstrated large increases in interstitial glutamate at about this time (Taylor et al., 1995). Although not measured in the present study, elevated glutamate would produce direct activation of ligand-gated cation channels and secondary stimulation of voltage-gated channels. Resulting ion conductances might contribute to or mediate observed intracellular elemental changes. Mitochondrial $\mathrm{Ca}$ accumulation after 5 min of OGD was twofold higher than that of either cytoplasm or nuclei, which likely reflects the buffering role of this organelle (Guenter et al., 1994). Although we did not attempt to dissect the relative contribution of internal (e.g., 
Table 4. Elemental composition and water content of CA1 nerve cells exposed to OGD or OGD/reoxygenation (OGD/ROX) at $36^{\circ} \mathrm{C}$ or $31^{\circ} \mathrm{C}$

\begin{tabular}{|c|c|c|c|c|}
\hline & $\mathrm{P}$ & $\mathrm{Cl}$ & $\mathrm{Mg}$ & Water \\
\hline \multicolumn{5}{|l|}{ Cytoplasm } \\
\hline $0 \min (93)$ & $609 \pm 35$ & $265 \pm 17$ & $25 \pm 4$ & $75 \pm 1$ \\
\hline $2 \min (47)$ & $528 \pm 15^{*}$ & $185 \pm 5^{*}$ & $19 \pm 1^{*}$ & $71 \pm 1^{*}$ \\
\hline $5 \min (50)$ & $518 \pm 9^{*}$ & $234 \pm 9$ & $9 \pm 1^{*}$ & $74 \pm 2$ \\
\hline $12 \min (60)$ & $452 \pm 10^{*}$ & $324 \pm 14$ & $2 \pm 1^{*}$ & $75 \pm 1$ \\
\hline $42 \min (46)$ & $541 \pm 21^{*}$ & $432 \pm 29^{*}$ & $0 \pm 1^{*}$ & $84 \pm 1^{*}$ \\
\hline OGD/ROX-36 ${ }^{\circ} \mathrm{C}(72)$ & $439 \pm 8^{*}$ & $690 \pm 20^{*}$ & $1 \pm 0^{*}$ & $83 \pm 1^{*}$ \\
\hline OGD/ROX-31 $1^{\circ} \mathrm{C}(90)$ & $510 \pm 14^{*}$ & $411 \pm 24^{*}$ & $13 \pm 2^{*}$ & $75 \pm 1^{* *}$ \\
\hline \multicolumn{5}{|l|}{ Mitochondria } \\
\hline $0 \min (46)$ & $776 \pm 70$ & $351 \pm 28$ & $29 \pm 8$ & $63 \pm 1$ \\
\hline $2 \min (27)$ & $576 \pm 22^{*}$ & $202 \pm 10^{*}$ & $14 \pm 2^{*}$ & $62 \pm 1$ \\
\hline $5 \min (29)$ & $615 \pm 17^{*}$ & $235 \pm 13^{*}$ & $14 \pm 2^{*}$ & $63 \pm 1$ \\
\hline $12 \min (28)$ & $546 \pm 14^{*}$ & $351 \pm 22^{*}$ & $2 \pm 1^{*}$ & $62 \pm 1$ \\
\hline $42 \min (32)$ & $581 \pm 33^{*}$ & $447 \pm 41^{*}$ & $0 \pm 1^{*}$ & $76 \pm 3^{*}$ \\
\hline $\mathrm{OGD} / \mathrm{ROX}-36^{\circ} \mathrm{C}(48)$ & $502 \pm 14^{*}$ & $825 \pm 28^{*}$ & $1 \pm 1^{*}$ & $79 \pm 1^{*}$ \\
\hline $\mathrm{OGD} / \mathrm{ROX}-31^{\circ} \mathrm{C}(67)$ & $556 \pm 19^{*}$ & $236 \pm 17^{*}, * *$ & $24 \pm 2 * *$ & $65 \pm 1^{* *}$ \\
\hline \multicolumn{5}{|l|}{ Nucleus } \\
\hline $0 \min (29)$ & $758 \pm 81$ & $245 \pm 31$ & $31 \pm 6$ & $62 \pm 1$ \\
\hline $2 \min (16)$ & $615 \pm 25^{*}$ & $186 \pm 11$ & $17 \pm 3^{*}$ & $63 \pm 2$ \\
\hline $5 \min (20)$ & $558 \pm 19^{*}$ & $185 \pm 22$ & $14 \pm 2^{*}$ & $63 \pm 3$ \\
\hline $12 \min (19)$ & $490 \pm 17^{*}$ & $347 \pm 36$ & $5 \pm 2^{*}$ & $70 \pm 3^{*}$ \\
\hline $42 \min (23)$ & $423 \pm 34^{*}$ & $534 \pm 50^{*}$ & $3 \pm 2^{*}$ & $81 \pm 2^{*}$ \\
\hline $\mathrm{OGD} / \mathrm{ROX}-36^{\circ} \mathrm{C}(41)$ & $450 \pm 45^{*}$ & $760 \pm 37^{*}$ & $2 \pm 1^{*}$ & $77 \pm 1^{*}$ \\
\hline $\mathrm{OGD} / \mathrm{ROX}-31^{\circ} \mathrm{C}(42)$ & $580 \pm 20^{*}$ & $185 \pm 21^{*}, * *$ & $26 \pm 3^{* *}$ & $61 \pm 1$ \\
\hline
\end{tabular}

Slices were incubated in control conditions or were exposed to oxygen/glucose deprivation (OGD) for 2, 5, 12, or 42 min. The (0) time-point represents pooled control data as described in Table 2. In additional studies, slices were exposed to $12 \mathrm{~min}$ of OGD followed by reoxygenation with normal oxygenated aCSF for 30 min at $36^{\circ} \mathrm{C}$ $\left(\mathrm{OGD} / \mathrm{ROX}-36^{\circ} \mathrm{C}\right)$ or $31^{\circ} \mathrm{C}\left(\mathrm{OGD} / \mathrm{ROX}-31^{\circ} \mathrm{C}\right)$. Data are expressed as mean millimoles of element per kilogram of dry weight \pm SEM. Numbers in parentheses represent analyses per experimental condition. *Significantly different $(p<0.05)$ from pooled control; ** significantly different $(p<0.05)$ from reoxygenation at $36^{\circ} \mathrm{C}$.

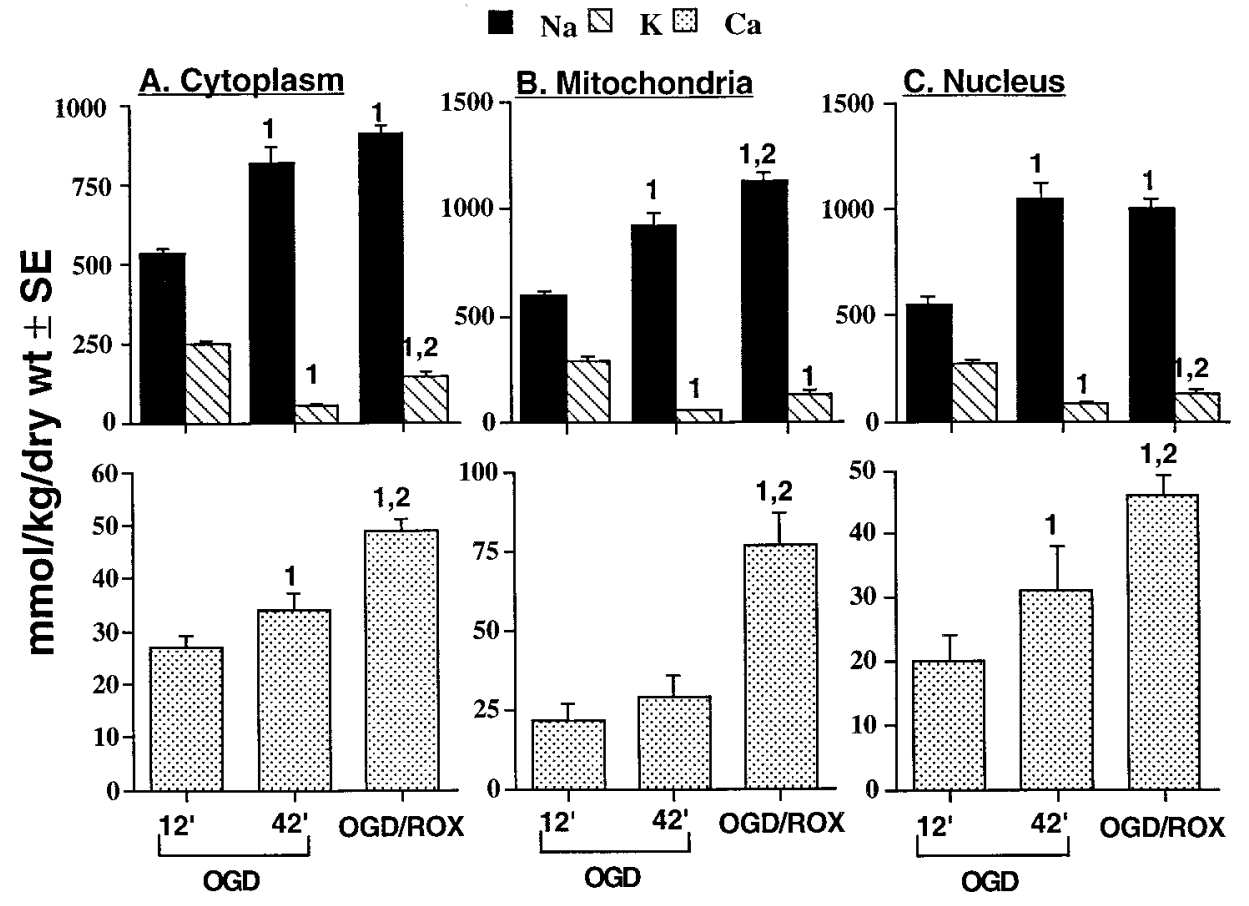

Figure 4. Mean ( \pm SEM) dry weight $\mathrm{Na}, \mathrm{K}$, and $\mathrm{Ca}$ concentrations (millimoles of element per kilogram) in cytoplasm $(A 4)$, mitochondria (B4), and nucleus (C4) of CA1 nerve cells from rat hippocampal slices. Slices were exposed to oxygen/glucose-deficient aCSF for 12 or 42 min (OGD). To measure changes in cellular elemental composition during reoxygenation $(R O X)$, hippocampal slices were exposed to OGD for $12 \mathrm{~min}$ followed by $30 \mathrm{~min}$ of perfusion with normal oxygenated aCSF $(O G D / R O X)$. $C$, Pooled control data as presented in Table 2. Top graphs present $\mathrm{Na}$ and $\mathrm{K}$ data; bottom graphs present $\mathrm{Ca}$ data. 1 indicates significantly different $(p<0.05)$ from $12 \mathrm{~min}\left(12^{\prime}\right)$ OGD data; 2 indicates significantly different $(p<0.05)$ from $42 \mathrm{~min}$ $\left(42^{\prime}\right)$ OGD data. release from smooth endoplasmic reticulum) versus external $\mathrm{Ca}^{2+}$ pools to increased mitochondrial $\mathrm{Ca}$ content, influx of $\mathrm{Ca}^{2+}$ o appears to be a primary source based on the low intraneuronal baseline levels versus the magnitude of OGD-induced net $\mathrm{Ca}$ increases. The route(s) of $\mathrm{Ca}^{2+}$ o entry during OGD has not been identified conclusively, although several studies suggest a complex interaction among glutamate receptor-coupled $\mathrm{Ca}^{2+}$ conductances, voltage-dependent $\mathrm{Ca}^{2+}$ channels, and reverse $\mathrm{Na}^{+} / \mathrm{Ca}^{2+}$-exchanges (Lobner and Lipton, 1993; Hoyt et al., 1998). 
Figure 5. Mean $( \pm$ SEM) dry weight $\mathrm{Na}, \mathrm{K}$, and $\mathrm{Ca}$ concentrations (millimoles of element per kilogram) in cytoplasm $(5 A)$, mitochondria $(5 B)$, and nucleus $(5 C)$ of CA1 nerve cells from rat hippocampal slices. Slices were exposed to oxygen/glucose-deficient aCSF for $12 \mathrm{~min}$ followed by incubation with normal medium for $30 \mathrm{~min}(O G D / R O X)$. To assess the potential neuroprotective effect of hypothermia, aCSF temperature was maintained at either $36^{\circ} \mathrm{C}$ or $31^{\circ} \mathrm{C}$ throughout the ischemic and postischemic periods. $C$, Pooled control data as presented in Table 2. Number of analyses per compartment is presented in Table 4. Top graphs present $\mathrm{Na}$ and $\mathrm{K}$ data; bottom graphs present $\mathrm{Ca}$ data. 1 indicates significantly different $(p<0.05)$ from control $(C) ; 2$ indicates significantly different $(p<0.05)$ from reoxygenation at $36^{\circ} \mathrm{C}$.

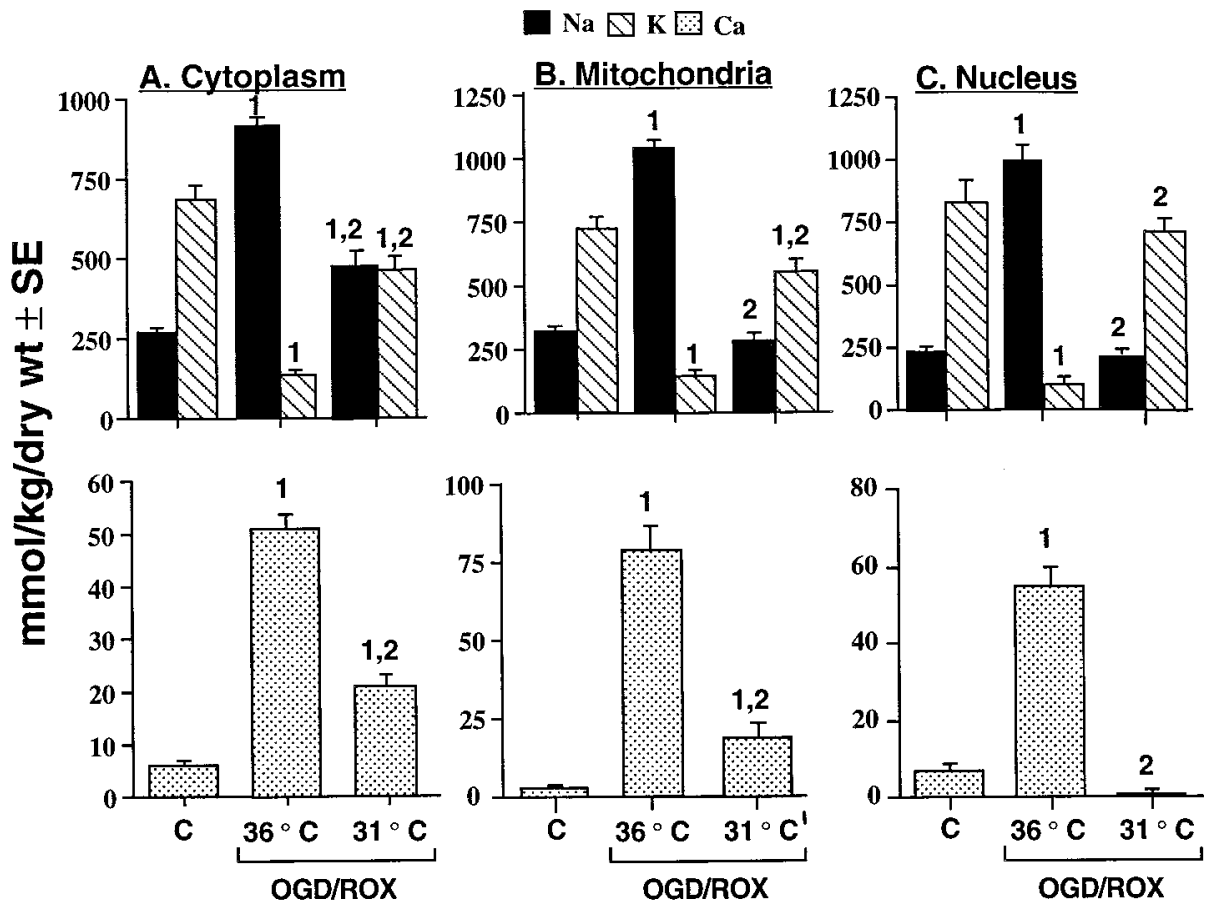

Continuation of oxygen/glucose deprivation (12-42 min) progressively intensified $\mathrm{Na}, \mathrm{K}$, and $\mathrm{Mg}$ changes in all compartments. Although cytoplasmic $\mathrm{Ca}$ accumulation continued at a near linear pace over the 12-42 min period, Ca levels in mitochondrial and nuclear regions decreased or remained constant relative to the $5 \mathrm{~min}$ data. The mechanism of truncated mitochondrial $\mathrm{Ca}$ accumulation and abrupt egress is uncertain. It is possible that this represents $\mathrm{Ca}^{2+}$ efflux from mitochondria via extramitochondrial $\mathrm{Na}^{+}$-stimulated $\mathrm{Na}^{+}-\mathrm{Ca}^{2+}$ exchange (White and Reynolds, 1997). Alternatively, Ca loss might be mediated by OGDinduction of mitochondrial permeability transition (mPT). mPT is characterized by opening of a proteinaceous inner mitochondrial pore with subsequent loss of membrane potential, rapid $\mathrm{Ca}^{2+}$ efflux, and leakiness to $\mathrm{K}^{+}, \mathrm{Mg}^{2+}$, and other solutes (Bernardi et al., 1994). A growing body of evidence suggests that $\mathrm{mPT}$ and resulting mitochondrial dysfunction are importantly involved in ischemic/hypoxic neuronal injury (Guenter et al., 1994; Kristian and Siesjo, 1996; White and Reynolds, 1996; Kristal and Dubinsky, 1997). Regardless, loss of mitochondrial $\mathrm{Ca}^{2+}$ buffering and resulting increased cytoplasmic $\mathrm{Ca}^{2+}$ burden could contribute significantly to ischemic damage of CA1 nerve cells (Kristian and Siesjo, 1996).

\section{An exacerbated neuronal $\mathrm{Ca}^{2+}$ burden characterizes reoxygenation injury}

Previous research demonstrated a lack of functional synaptic recovery during post-OGD reperfusion of hippocampal slices (Balestrino et al., 1989; Boening et al., 1989; Taylor and Weber, 1993; Weber and Taylor, 1994). Similarly, in our study of CA1 cells reoxygenated after $12 \mathrm{~min}$ of OGD, evoked EPSPs were absent and cellular elemental composition was severely disturbed. Thus, elemental deregulation initiated during OGD worsened despite restoration of normal oxygen and glucose perfusion. This severe level of disruption was similar to the extent of element and water deregulation produced by $42 \mathrm{~min}$ of continuous OGD, with the exception that reoxygenation was distinguished by selective exacerbation of $\mathrm{Ca}$ entry and compartmental accumulation. Nei- ther the corresponding mechanism nor pathophysiological implications of this augmented $\mathrm{Ca}^{2+}$ entry are fully understood. However, it should be noted that net mitochondrial $\mathrm{Ca}$ accumulation during reoxygenation was substantial and surpassed that of either cytoplasm or nuclei. Uniporter-mediated $\mathrm{Ca}^{2+}$ transport can dissipate the mitochondrial membrane potential and thereby interfere with energy production (Guenter et al., 1994). That mitochondria from reoxygenated neurons are dysfunctional is suggested by the extent of general elemental disruption and loss of osmoregulation observed in the present study. Severe mitochondrial impairment after post-ischemia recirculation has been documented previously (Rehncrona et al., 1979; Hillered et al., 1984; Sims, 1991; Almeida et al., 1995), and injured mitochondria are considered to be a significant source of reactive oxygen species that might additionally contribute to neuronal reperfusion injury (Vlessis et al., 1990; Dykens, 1994; Reynolds and Hastings, 1995; White and Reynolds, 1996). Amplification of cell $\mathrm{Ca}^{2+}$ burden and associated mitochondrial dysfunction caused by reoxygenation might therefore be responsible for, or contribute to, the inability of neurons to recover from transient OGD (Young, 1986; Siesjo, 1992).

\section{Calculated neuronal ionic concentrations}

Aqueous ionic (millimolar) concentrations of elements can be calculated from respective EPMA-derived millimoles of element per kilogram of dry weight and percentage water data (LoPachin and Stys, 1995; Stys et al., 1997). Thus, when mu concentrations of major diffusable ions are calculated for control CA1 nerve cells, results are higher than anticipated; i.e., $\mathrm{Na}^{+}=60 \mathrm{~mm}, \mathrm{Cl}^{-}$ $=83 \mathrm{~mm}$, and $\mathrm{K}^{+}=188 \mathrm{~mm}$. A similar discrepancy exists when ionic concentrations were calculated based on EPMA data from rat dorsal root ganglion nerve cells (LoPachin et al., 1988). During OGD and reoxygenation of hippocampal slices, total intraneuronal elemental content rose progressively but was not accompanied by compensatory increases in cell water of equal magnitude (Fig. 3, Table 4). These observations apparently contradict the principle of osmolarity and therefore might reflect 
methodological problems such as inaccurate water or element measurements. However, that EPMA can provide reliable and accurate information is suggested by a control mean ( \pm SEM) neuronal water content of $75 \pm 1 \%$ (Table 4), which corresponds to accepted values (75-80\%) (Macknight, 1987). Moreover, recent work in CNS and PNS nerves has shown that EPMA-based calculations of control axonal resting membrane potentials, free $\mathrm{Na}^{+}, \mathrm{K}^{+}$, and $\mathrm{Cl}^{-}$concentrations, and corresponding ion equilibrium potentials are in close agreement with previously published results derived by other electrophysiological or analytical methods (Stys et al., 1997). Because EPMA cannot distinguish ionic versus bound element, the discrepancy between estimated and expected ion concentrations for CA1 neurons likely results from inclusion of a nonexchangeable fraction in calculations of aqueous ion concentrations. These results also suggest that nerve soma contains a relatively large bound or ionically inactive fraction of Na, K, and Cl (Brinley, 1967; Woodward et al., 1969; Brown and Scholfield, 1974), whereas these elements in axons are primarily ionized (Walker and Brown, 1977).

\section{Hypothermia and neuroprotection}

The effects of hypothermia $\left(31^{\circ} \mathrm{C}\right)$ on $\mathrm{OGD} /$ reoxygenationinduced CA1 cell elemental disruption were also investigated. Previous research indicates that moderate hypothermia $\left(30-31^{\circ} \mathrm{C}\right)$ during transient ischemia and reperfusion can modify associated structural and functional perturbations; e.g., hypothermia prevented histopathological changes (Morikawa et al., 1992), retarded tissue $\mathrm{Ca}^{2+}$ accumulation (Mitani et al., 1991), glutamate release (Globus et al., 1988), free radical activity (Globus et al., 1995), and membrane depolarization (Onitsuka et al., 1998), and promoted recovery of synaptic potentials (Taylor and Weber, 1993). In our study, incubation of hippocampal slices at $31^{\circ} \mathrm{C}$ provided nearly complete protection against neuronal element and water deregulation induced by OGD/reoxygenation. In addition, hypothermia mostly preserved postsynaptic potentials. It is notable that near-normal cellular $\mathrm{Mg}$ contents were maintained during hypothermia because this element is closely associated with functional viability (Alvarez-Leefmans et al., 1987). For mitochondria in particular, preservation of $\mathrm{Mg}$ has potential significance because $\mathrm{Mg}^{2+}$ moderates both mitochondrial $\mathrm{Ca}^{2+}$ uptake and formation of the transition pore (Guenter et al., 1994; Novgorodov et al., 1994). Regardless, it is not known how hypothermia lessens synaptic dysfunction and ion perturbation induced by OGD/reoxygenation. It is likely that acute neuronal recovery during hypothermia is facilitated by a reduction in ATP consumption and cellular $\mathrm{Ca}^{2+}$ burden that appears to correspond to preservation of mitochondrial and nuclear ion distribution and function (Erecinska and Silver, 1994; Globus et al., 1995). In addition, moderation of elevated cytosolic $\mathrm{Ca}^{2+}$ concentrations during hypothermia could prevent activation of calcium-stimulated proteases (calpains) that might play a role in ischemia-induced neuronal damage (Wang and Yuen, 1994). Inhibition of nuclear $\mathrm{Ca}$ accumulation by hypothermia could also prevent $\mathrm{Ca}^{2+}$ activation of cell-death genes that might mediate delayed-onset ischemia-induced neurodegeneration (Nitatori et al., 1995).

\section{Conclusions}

In vitro exposure of rat hippocampal slices to experimental ischemia produced early ( 2 min OGD) decreases in intraneuronal concentrations of $\mathrm{K}, \mathrm{Cl}, \mathrm{P}$, and $\mathrm{Mg}$. Continued OGD was associated with more extensive derangement of subcellular elemental composition characterized by significantly elevated $\mathrm{Na}, \mathrm{Cl}$, and $\mathrm{Ca}$ levels and progressive $\mathrm{K}$ and $\mathrm{Mg}$ losses. The onset of intraneuronal elemental disturbance during hippocampal OGD was temporally correlated to developing cellular morphological alterations and synaptic deficits. This suggests that $\mathrm{K}^{+}$loss and $\mathrm{Na}^{+} / \mathrm{Ca}^{2+}$ gains in deprived CA1 cells are causally linked to induction of structural and functional perturbations (Hansen, 1985; Choi, 1988, 1995; Lobner and Lipton, 1993; Martin et al., 1994). Post-OGD superfusion of slices with oxygenated, glucosecontaining media did not promote CA1 cell recovery, and instead intraneuronal elemental disruption continued to deteriorate. The observed patterns of ion translocation that characterize reoxygenated individual subcellular organelles (mitochondria, nuclei) might play a critical role in mediating early and delayed consequences of transient ischemia (Nitatori et al., 1995; Kristian and Siesjo, 1996; White and Reynolds, 1996, 1997). Regardless, our findings suggest that hypothermia might be neuroprotective because of slowing of this ion redistribution and consequential preservation of subcellular ion composition and organelle function. The present study has provided detailed, previously unavailable data regarding the extent and magnitude of ion deregulation in OGD/reoxygenation-injured CNS nerve cells. Such information represents a basis for refining our understanding of ischemic nerve injury and for development and testing of potential neuroprotective strategies.

\section{REFERENCES}

Almeida A, Allen KL, Bates TE, Clark JB (1995) Effect of reperfusion following cerebral ischaemia on the activity of the mitochondrial respiratory chain in the gerbil brain. J Neurochem 65:1698-1703.

Alvarez-Leefmans FJ, Giraldez F, Gamino SM (1987) Intracellular free magnesium in excitable cells: its measurement and its biologic significance. Can J Physiol Pharmacol 65:915-925.

Andersen P, Lomo T (1966) Mode of activation of hippocampal pyramidal cells by excitatory synapses on dendrites. Exp Brain Res 2:247-260.

Balestrino M, Aitken PG, Somjen GG (1989) Spreading depression-like hypoxic depolarization in CA 1 and fascia dentata of hippocampal slices: relationship to selective vulnerability. Brain Res 102-107.

Bernardi P, Broekemeier KM, Pfeiffer DR (1994) Recent progress on regulation of the mitochondrial permeability transition pore: a cyclosporin-sensitive pore in the inner mitochondrial membrane. J Bioenerg Biomembr 26:509-517.

Boening JA, Kass IS, Cottrell JE, Chambers G (1989) The effect of blocking sodium influx on anoxic damage in the rat hippocampal slice. Neuroscience 33:263-268.

Brinley FJ (1967) Potassium accumulation and transport in the rat sympathetic ganglion. J Neurophysiol 30:1531-1560.

Brown DA, Scholfield CN (1974) Changes in intracellular sodium and potassium ion concentrations in isolated rat superior cervical ganglia induced by depolarizing agents. J Physiol (Lond) 242:307-319.

Bulger RE, Beeuwkes R, Saubermann AJ (1981) Application of scanning electron microscopy to x-ray analysis of frozen-hydrated sections. III. Elemental content of cells in the rat renal papillary tip. J Cell Biol 88:274-280.

Choi DW (1988) Calcium-mediated neurotoxicity: relationship to specific channel types and role in ischemic damage. Trends Neurosci 11:465-469.

Choi DW (1995) Calcium: still center-stage in hypoxic-ischemic neuronal death. Trends Neurosci 18:58-60.

Dykens JA (1994) Isolated cerebral and cerebellar mitochondria produce free radicals when exposed to elevated $\mathrm{Ca}^{2+}$ and $\mathrm{Na}^{+}$: implications for neurodegeneration. J Neurochem 63:584-591.

Enseleit WH, Domer FR, Jarrott DM, Baricos WH (1984) Cerebral phospholipid content and $\mathrm{Na}, \mathrm{K}-\mathrm{ATP}$ ase activity during ischemia and postischemic reperfusion in the Mongolian gerbil. J Neurochem 43:320-327.

Erecinska M, Silver IA (1994) Ions and energy in mammalian brain. Prog Neurobiol 43:37-71. 
Foster MC, Saubermann AJ (1991) Personal-computer-based system for electron beam X-ray microanalysis of biological samples. J Microsc 161:367-373.

Globus MY-T, Busto R, Dietrich WD, Martinez E, Valdes I, Ginsberg MD (1988) Intra-ischemic extracellular release of dopamine and glutamate is associated with striatal vulnerability to ischemia. Neurosci Lett 91:36-40.

Globus MY-T, Busto R, Lin B, Schnippering H, Ginsberg MD (1995) Detection of free radical activity during transient global ischemia and recirculation: effects of intra-ischemic brain temperature modulation. J Neurochem 65:1250-1256.

Guenter TD, Gunter KK, Sheu SS, Gavin CE (1994) Mitochondrial calcium transport: physiological and pathological relevance. Am J Physiol 267:C313-C339.

Hall TA, Anderson HC, Appleton T (1973) The use of thin specimens for x-ray microanalysis in biology. J Microsc 99:177-182.

Hansen AJ (1985) Effect of anoxia on ion distribution in the brain. Physiol Rev 65:101-148.

Hansen AJ, Zeuthen T (1981) Extracellular ion concentrations during spreading depression and ischemia in rat brain cortex. Acta Physiol Scand 113:437-445.

Hansen AJ, Hounsgaard J, Jahnsen H (1982) Anoxia increases potassium conductance in hippocampal nerve cells. Acta Physiol Scand 115:301-310.

Harris RJ, Symon L, Branston NM, Bayham M (1981) Changes in extracellular calcium activity in cerebral ischemia. J Cereb Blood Flow Metab 1:203-209.

Hernandez-Cruz A, Sala F, Adams PR (1990) Subcellular calcium transients visualized by confocal microscopy in a voltage-clamped vertebrate neuron. Science 247:858-862.

Hillered L, Siesjo BK, Arfors KE (1984) Mitochondrial response to transient forebrain ischemia and recirculation in the rat. J Cereb Blood Flow Metab 4:438-446.

Hossmann KA (1996) Peri-infarct depolarizations. Cerebrovasc Brain Metab Rev 8:195-208.

Hoyt HR, Arden SR, Aizenman E, Reynolds IJ (1998) Reverse $\mathrm{Na}^{+}$/ $\mathrm{Ca}^{2+}$ exchange contributes to glutamate-induced intracellular $\mathrm{Ca}^{2+}$ concentration increases in cultured rat forebrain neurons. Mol Pharmacol 53:742-749.

Jiang C, Haddad GG (1991) Effect of anoxia on intracellular and extracellular potassium activity in hypoglossal neurons in vitro. J Neurophysiol 66:103-111.

Katsura K, Minamisava H, Ekholm A, Folbergrova J, Siesjo BK (1992) Changes of labile metabolites during anoxia in moderately hypo- and hyperthermic rats: correlation to membrane fluxes of $\mathrm{K}^{+}$. Brain Res 590:6-12.

Kocsis JD, Rand MN, Chen B, Waxman SG, Pourcho R (1993) Kainate elicits elevated nuclear calcium signals in retinal neurons via calciuminduced calcium release. Brain Res 616:273-282.

Kristal BS, Dubinsky JM (1997) Mitochondrial permeability transition in the central nervous system: induction by calcium cycling-dependent and -independent pathways. J Neurochem 69:524-538.

Kristian T, Siesjo BK (1996) Calcium-related damage in ischemia. Life Sci 59:357-367.

Leblond J, Krnjevic K (1989) Hypoxic changes in hippocampal neurons. J Neurophysiol 62:1-14.

LeFurgey A, Spencer AJ, Jacobs WR, Ingram P, Mandel LJ (1991) Elemental microanalysis of organelles in proximal tubules. I. Alterations in transport and metabolism. J Am Soc Nephrol 1:1305-1320.

Lipton P, Whittingham TS (1982) Reduced ATP concentrations: a basis for synaptic transmission failure during hypoxia in the in vitro guineapig hippocampus. J Physiol (Lond) 325:51-65.

Lobner D, Lipton P (1993) Intracellular calcium levels and calcium fluxes in the CA 1 region of the rat hippocampal slice during in vitro ischemia: relationship to electrophysiological cell damage. J Neurosci 13:4861-4871.

LoPachin RM (1995) Electron probe X-ray microanalysis as a tool for discerning mechanism of nerve injury. In: Neurotoxicology: approaches and methods (Chang L, Slikker W, eds), pp 445-453. San Diego: Academic.

LoPachin RM, Lehning EJ (1997) Mechanism of calcium entry during axon injury and degeneration. Toxicol Appl Pharmacol 143:233-244.

LoPachin RM, Stys P (1995) Elemental composition and water content of rat optic nerve myelinated axons and glial cells: effects of in vitro anoxia and reoxygenation. J Neurosci 15:6735-6746.
LoPachin RM, Lowery J, Eichberg J, Kirkpatrick JB, Cartwright J, Saubermann AJ (1988) Distribution of elements in rat peripheral axons and nerve cell bodies determined by x-ray microprobe analysis. J Neurochem 51:764-775.

LoPachin RM, Castiglia CM, Saubermann AJ (1991) Elemental composition and water content of myelinated axons and glial cells in rat central nervous system. Brain Res 549:253-259.

Macknight ADC (1987) Volume maintenance in isosmotic conditions. Curr Topics Membr Transp 30:3-43.

Martin RL, Lloyd HGE, Cowan AI (1994) The early events of oxygen and glucose deprivation: setting the scene for neuronal death? Trends Neurosci 17:251-257.

Mitani A, Kakoya F, Kataoka K (1991) Temperature dependence of hypoxia-induced calcium accumulation in gerbil hippocampal slices. Brain Res 562:159-163.

Moghaddam B, Schenk JO, Stewart WB, Hansen AJ (1986) Temporal relationship between neurotransmitter release and ion flux during spreading depression and anoxia. Can J Physiol Pharmacol 65:1105-1110.

Morikawa E, Ginsberg MD, Dietrich WD, Duncan RC, Kraydieh S, Globus MY-T, Busto R (1992) The significance of brain temperature in focal cerebral ischemia: histopathological consequences of middle cerebral artery occlusion in the rat. J Cereb Blood Flow Metab 12:380-389.

Murphy KPSJ, Greenfield SA (1992) Neuronal selectivity of ATPsensitive potassium channels in guinea-pig substantia nigra revealed by responses to anoxia. J Physiol (Lond) 453:167-183.

Nitatori T, Sata N, Wafuri S, Karasawa Y, Araki H, Shibanai K, Kominami E, Uchiyama Y (1995) Delayed neuronal death in the CA 1 pyramidal cell layer of the gerbil hippocampus following transient ischemia is apoptosis. J Neurosci 15:1001-1011.

Novgorodov SA, Gudz TI, Brierley GP, Pfeiffer DR (1994) Magnesium ion modulates the sensitivity of the mitochondrial permeability transition pore to cyclosporin A and ADP. Arch Biochem Biopsyiol 311:219-228.

Onitsuka M, Mihara S, Inokuchi H, Shigemori M, Higashi H (1998) Mild hypothermia protects rat hippocampal CA1 neurons from irreversible membrane dysfunction induced by experimental ischemia. Neurosci Res 30:1-6.

Peters A, Palay SL, Webster HD (1991) The neuronal cell body. In: The fine structure of the nervous system: neurons and their supporting cells, ed 3, pp 14-69. New York: Oxford UP.

Przywara DA, Behave S, Behave A, Wakade TD, Wakade AR (1991) Stimulated rise in neuronal calcium is faster and greater in the nucleus than the cytosol. FASEB J 5:217-222.

Rehncrona S, Mela L, Siesjo BK (1979) Recovery of brain mitochondrial function in the rat after complete and incomplete cerebral ischemia. Stroke 10:437-446.

Reynolds IJ, Hastings TG (1995) Glutamate induces the production of reactive oxygen species in cultured forebrain neurons following NMDA receptor activation. J Neurosci 15:3318-3327.

Saubermann AJ, Heyman RV (1987) Quantitative digital x-ray imaging using frozen hydrated and frozen dried tissue sections. J Microsc 146:169-182.

Saubermann AJ, Beeuwkes R, Peters PD (1981a) Application of scanning electron microscopy to X-ray analysis of frozen-hydrated sections. II. Analysis of standard solutions and artificial electrolyte gradients. J Cell Biol 88:268-273.

Saubermann AJ, Echlin P, Peters PD, Beeuwkes R (1981b) Application of scanning electron microscopy to X-ray analysis of frozen-hydrated sections. I. Specimen handling techniques. J Cell Biol 88:257-267.

Saubermann AJ, Castiglia CM, Foster MC (1992) Preferential uptake of rubidium from extracellular space by glial cells compared to neurons in leech ganglia. Brain Res 577:64-72.

Siesjo BK (1992) Pathophysiology and treatment of focal cerebral ischemia. Part I: pathophysiology. J Neurosurg 77:169-184.

Silver IA, Erecinska M (1990) Intracellular and extracellular changes of $\left[\mathrm{Ca}^{2+}\right]$ in hypoxia and ischemia in rat brain in vivo. J Gen Physiol 95:837-866.

Silver IA, Deas J, Erecinska M (1997) Ion homeostasis in brain cells: differences in intracellular ion responses to energy limitation between cultured neurons and glial cells. Neuroscience 78:589-601.

Sims NR (1991) Selective impairment of respiration in mitochondrial 
isolated from brain subregions following transient forebrain ischemia in the rat. J Neurochem 56:1836-1844.

Somjen GG, Aitken PG, Balestrino M, Herreras O, Kawasaki K (1990) Spreading depression-like depolarization and selective vulnerability of neurons: a brief review. Stroke [Suppl III] 21:III-179-III-183.

Somlyo AP, Urbanics R, Vadasz G, Kovach AGB, Somlyo AV (1985) Mitochondrial calcium and cellular electrolytes in brain cortex frozen in situ: electron probe analysis. Biochem Biopsy Res Commun 132:1071-1078.

Stys PK, Lehning EJ, Saubermann AJ, LoPachin RM (1997) Intracellular concentrations of major ions in rat myelinated axons and glia: calculations based on electron probe X-ray microanalysis. J Neurochem 68:1920-1928.

Taylor CP, Weber ML (1993) Effect of temperature on synaptic function after reduced oxygen and glucose in hippocampal slices. Neuroscience 52:555-562.

Taylor CP, Burke SP, Weber ML (1995) Hippocampal slices: glutamate release and cellular damage from ischemia are reduced by sodium channel blockade. J Neurosci Methods 59:121-128.

Vlessis AA, Widener LL, Bartos D (1990) Effect of peroxide, sodium, and calcium on brain mitochondrial respiration in vitro: potential role in cerebral ischemia and reperfusion. J Neurochem 54:1412-1418.
Walker JL, Brown HM (1977) Intracellular ionic activity measurements in nerve and muscle. Physiol Rev 57:729-781.

Wang KW, Yuen P-W (1994) Calpain inhibition: an overview of its therapeutic potential. Trends Pharmacol Sci 15:412-419.

Weber ML, Taylor CP (1994) Damage from oxygen and glucose deprivation in hippocampal slices is prevented by tetrodotoxin, lidocaine and phenytoin without blockade of action potentials. Brain Res 664:167-177.

White RJ, Reynolds IJ (1996) Mitochondrial depolarization in glutamate-stimulated neurons: an early signal specific to excitotoxin exposure. J Neurosci 15:5688-5697.

White RJ, Reynolds IJ (1997) Mitochondria accumulate $\mathrm{Ca}^{2}+$ following intense glutamate stimulation of cultured rat forebrain neurons. J Physiol (Lond) 498:31-47.

Woodward JK, Bianchi CP, Erulkar SD (1969) Electrolyte distribution in rabbit superior cervical ganglion. J Neurochem 16:289-299.

Young W (1986) Ca paradox in neural injury: a hypothesis. Cent Nerv Syst Trauma 3:235-251.

Zetterstrom TSC, Vaughan-Jones RD, Grahame-Smith DG (1995) A short period of hypoxia produces a rapid and transient rise in $\left[\mathrm{K}^{+}\right]_{\mathrm{e}}$ in rat hippocampus in vivo which is inhibited by certain $\mathrm{K}^{+}$-channel blocking agents. Neuroscience 67:815-821. 